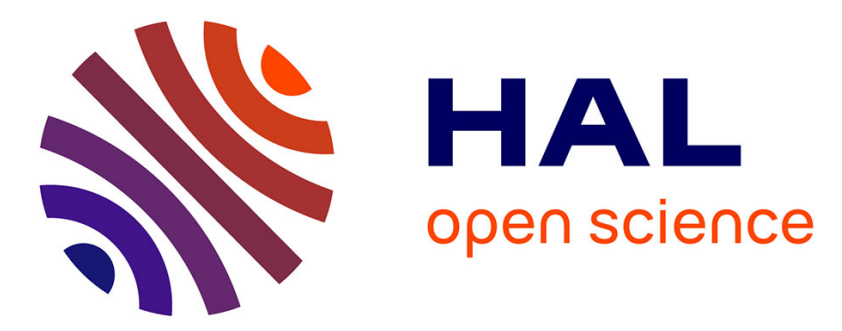

\title{
Similarities and Differences Between HCV Pseudoparticle (HCVpp) and Cell Culture HCV (HCVcc) in the Study of HCV
}

Laura Riva, Jean Dubuisson

\section{- To cite this version:}

Laura Riva, Jean Dubuisson. Similarities and Differences Between HCV Pseudoparticle (HCVpp) and Cell Culture HCV (HCVcc) in the Study of HCV. Mansun Law. Hepatitis C Virus Protocols, 1911, Springer, pp.33-45, 2019, Methods in Molecular Biology, 10.1007/978-1-4939-8976-8_2 . hal02112507

\section{HAL Id: hal-02112507 \\ https://hal.science/hal-02112507}

Submitted on 26 Apr 2019

HAL is a multi-disciplinary open access archive for the deposit and dissemination of scientific research documents, whether they are published or not. The documents may come from teaching and research institutions in France or abroad, or from public or private research centers.
L'archive ouverte pluridisciplinaire HAL, est destinée au dépôt et à la diffusion de documents scientifiques de niveau recherche, publiés ou non, émanant des établissements d'enseignement et de recherche français ou étrangers, des laboratoires publics ou privés. 
Similarities and differences between HCV pseudoparticle (HCVpp) and cell culture

$\mathrm{HCV}$ (HCVec) in the study of $\mathrm{HCV}$

Laura Riva and Jean Dubuisson*

Univ. Lille, CNRS, Inserm, CHU Lille, Institut Pasteur de Lille, U1019 - UMR 8204 - CIIL -

Centre d'Infection et d'Immunité de Lille, F-59000 Lille, France

*Corresponding authors

E-mail: jean.dubuisson@ibl.cnrs.fr

Running Head: Comparison between HCVpp and HCVec

Keywords: Hepatitis C virus, HCVpp, HCVcc 


\begin{abstract}
For a long time, the study of the HCV infectious cycle has been a major challenge for researchers because of the difficulties in generating an efficient cell culture system leading to a productive viral infection. The development of HCVpp and later on HCVcc model allowing for functional studies of $\mathrm{HCV}$ in cell culture completely revolutionized HCV research. The aim of this review is to provide the reader with a brief overview of the development of these two models. We describe the advantages of each model as well as their limitations in the study of the HCV life cycle, with a particular emphasis on virus entry. A comparison between these two models is presented in terms of virion composition and their use as tools for the characterization of entry factors, envelope glycoproteins functions and antibody neutralization. We also compare the production and biosafety level of these two types of viral particles. Globally, this review provides a general description of the most adequate applications for HCVpp and HCVcc in HCV research.
\end{abstract}

\title{
1 Introduction
}

The identification of HCV genome, which was reported for the first time in 1989 [1], led to a new era in molecular and biochemical research on HCV. However, for a long time it remained impossible to propagate $\mathrm{HCV}$ in cell culture and this limited the understanding of virus-host interactions at the cellular and molecular levels. To circumvent these limitations, several groups have tried to develop surrogate models to study HCV entry or replication. Before the development of a cell culture system for HCV (HCVcc) in 2005 [2-4], selectable replicon systems [5] and retrovirus-based pseudotyped particles (HCVpp) [6-8] were major tools used to investigate $\mathrm{HCV}$ genomic replication and virus entry, respectively. In this 
review, we briefly present $\mathrm{HCVpp}$ and $\mathrm{HCVcc}$ systems and we discuss the similarities and differences between these two systems.

\subsection{The HCVpp system}

The development of the HCVpp system enabled for the first time to functionally investigate HCV entry. This model is based on the production of retroviral capsid particles, which incorporate in their lipid envelope unmodified HCV glycoproteins E1 and E2. This system was first described in 2003 by two different groups $[6,8]$ and since then it has been extensively used to investigate the mechanisms of HCV entry and characterize antibody neutralization.

HCVpp are generated through the co-transfection of 293T cells with three plasmids respectively coding for (i) a retroviral genome expressing a reporter gene, (ii) the gag-pol proteins from human immunodeficiency virus (HIV) or murine leukemia virus (MLV) and (iii) HCV E1 and E2 glycoproteins. The presence of a reporter gene, such as GFP or luciferase, allows for the quantification of pseudoparticle entry into target cells (Figure 1).

Even if HCV morphogenesis strongly differs from retroviral/lentiviral assembly and the cell surface is supposed to be the main location where retrovirus/lentivirus budding occurs, retroviral assembly has also been observed in the late endosomes/multi-vesicular bodies [9]. Moreover, overexpression of the HCV envelope glycoproteins in 293T cells leads to the export of a fraction of these proteins at the plasma membrane, which otherwise are retained in the endoplasmic reticulum [6-8]. Both these observations can explain the production of retroviral/lentiviral pseudoparticles containing HCV glycoproteins. The presence of $\mathrm{HCV}$ envelope proteins at the surface of $\mathrm{HCVpp}$ mediates interactions with $\mathrm{HCV}$ specific cellular entry factors as well as fusion with host membranes, whereas the following 
steps are mediated by the retroviral/lentiviral components of this chimeric particle. Therefore, HCVpp mimic HCV entry independently of the other steps of the HCV life cycle.

\subsection{The HCVec system}

After the identification of HCV genome in 1989 [1] and its characterization [10], the development of a cell culture system for this virus has been a slow process involving several crucial steps, which started with the identification of the 3' non-coding region of the genome [11]. This led to the construction of full-length cDNA clones of genotype 1a that were transcribed in vitro and tested for viral production. However, faced with a lack of replication in cell culture, productive viral replication had to be validated by intrahepatic inoculation of chimpanzees with genomic RNA generated in vitro, after the construction of a consensus clone $[12,13]$. These in vivo experiments encouraged the scientific community to continue the search for in vitro replication models.

The first development of a functional in vitro system for HCV replication appeared in 1999, with the construction of the first sub-genomic replicon of genotype $1 \mathrm{~b}$ [5]. This subgenomic replicon is characterized by a bi-cistronic construct containing an internal ribosome entry site (IRES) from encephalomyocarditis virus (EMCV). In this system, the HCV IRES controls the expression of neomycin phosphotransferase as a selection gene, while the EMCV IRES drives the expression of HCV non-structural (NS) proteins from NS3 to NS5B. All genes are under the control of a T7 promoter, necessary for the in vitro RNA transcription with a T7 RNA polymerase, in order to generate the viral RNA that once electroporated in Huh7 cells can give rise to self-replication [5]. The addition of G418 allows for the selection of Huh-7 cells electroporated with the viral RNA, in order to isolate cellular clones replicating HCV. The development of the subgenomic replicon system enabled the 
study of HCV replication, leading to the identification of viral proteins as well as cellular proteins participating in this step of the viral life cycle.

Replication represents an important step during the viral life cycle and it is an interesting target for the identification of antiviral compounds. Therefore, the establishment of subgenomic replicons gave a great impulse to the development of antiviral drugs directed against non-structural proteins. The currently used direct acting antivirals (DAAs), mainly targeting NS3, NS5A and NS5B, were validated in vitro on subgenomic replicons (reviewed in [14]).

After the assembly of functional subgenomic replicons, full-length genomes were reconstituted based on functional replicons. Unfortunately, transfection of hepatoma cells with such full-length replicons still did not lead to virion production [15-18]. This is due to the fact that efficient amplification of these replicons required replication enhancing mutations that impaired virus assembly [19]. Indeed, in addition to structural components, HCV non-structural proteins are also involved in virion assembly [20].

A major breakthrough in the development of a cell culture system for HCV came with the construction of a genotype 2 a subgenomic replicon which replicated with very high efficiency without the requirement of adaptive mutations [21]. This subgenomic replicon was cloned from a Japanese patient suffering from a fulminant hepatitis and it was designated “Japanese fulminant hepatitis 1" (JFH1) virus [22]. Later on, three groups reported that the complete wild-type JFH1 genome or chimeras consisting of the JFH1 replicase genes NS3NS5B and Core to NS2 regions of alternative HCV genomes replicated efficiently in Huh-7 cells and produced infectious viral particles [2-4]. These particles were designated HCVcc for cell culture-derived HCV, and they are now routinely used to study each step of the viral life cycle (Figure 1). During the following years, this system was further optimized thanks to the selection of adaptive mutations, which strongly increased the viral titers of the released 
virions [23-25].

\section{Differences in virion composition between HCVpp and HCVcc}

HCVcc particles are composed of the single-stranded RNA genome interacting with the core protein to form the nucleocapsid that is surrounded by a cell-derived lipid membrane in which the envelope glycoproteins E1 and E2 are anchored. In addition, HCV particles also contain host-derived components. Indeed, a specific feature of HCV virion is its interaction with very-low density lipoproteins (VLDL) or low-density lipoproteins (LDL), resulting in the formation of a lipo-viro-particle [26]. As a consequence, apolipoproteins such as apoE, apoB, apoA1 and apoC1 can also be found in association with $\mathrm{HCVcc}$ particles [27-29]. In addition, neutral lipids such as triglycerides and cholesteryl esters are also incorporated into HCVcc virions [28]. However, differences in densities between HCVcc and serum-derived virions suggest that the lipid composition of HCVcc does not totally reflect that of native viral particles [30].

The composition of HCVpp is very different from that of HCVcc. Indeed, the only HCV-specific components of HCVpp are the envelope glycoproteins, which are anchored in a host-derived membrane. The rest of the particle is composed of the retroviral/lentiviral core proteins as well as a packaging-competent retrovirus/lentivirus-derived genome harboring a marker gene. Therefore, only entry functions attributed to HCV envelope glycoproteins can be investigated with the HCVpp system. Furthermore, because of their production in kidney cells and their mode of assembly, HCVpp are not associated with lipoproteins, typically synthesized in hepatic cells. Moreover, ApoE is not found to be associated with HCVpp [31]. This therefore represents a major limitation for investigating the role of lipoprotein or lipid receptors in HCV entry. 
Differences in maturation are also observed between envelope glycoproteins associated with HCVpp and HCVcc. Indeed, differences in the glycosylation profiles were observed between HCVpp and HCVcc, suggesting that the accessibility of HCV glycans to Golgi glycosidases and/or glycosyltransferases is not the same for the two types of particles, due to differences in the assembly process. Furthermore, HCVcc-associated E1 and E2 envelope glycoproteins form large covalent complexes stabilized by disulfide bridges [32], whereas mainly non-covalent E1E2 heterodimers are found to be associated with HCVpp [33]. It has also to be pointed out that a higher degree of heterogeneity has also been observed in the envelope glycoproteins associated with HCVpp [34].

\subsection{Characterization of HCV entry factors with HCVpp and HCVec systems}

HCVpp have been extensively used for the characterization of HCV-specific host entry factors. Cellular entry factors like tetraspanin CD81 [35] and scavenger receptor class B type I (SR-BI) [36], previously identified by a biochemical approach using a truncated form of E2 as a bait, were confirmed to play a functional role in HCV entry with the help of HCVpp [37-38]. Later on, these entry factors were also confirmed with the HCVcc system [2, 3, 39]. HCVpp were also used in different large-scale screening approaches to identify new entry factors. Thanks to these screenings the tight-junction proteins claudin-1 [40] and occludin [41] were identified and characterized as essential players during the entry process. More recently, with the help of HCVpp, E-cadherin was shown to be an additional HCVspecific host entry factor [42]. Since its entry functions are uncoupled from other steps of the $\mathrm{HCV}$ life cycle, HCVpp have also been a major tool to confirm the role of novel HCVspecific host entry factors identified using the HCVcc system, as shown for the transferrin 
receptor 1 [43], the VLDL receptor [44], as well as the epidermal growth factor receptor (EGFR) and ephrin receptor A2 (EphA2) [45].

In contrast, some HCV-specific host entry factors could not be confirmed in the HCVpp system. This is the case for Niemann-Pick C1-like 1 (NPC1L1) [46] and serum response factor binding protein 1 (SRFBP1) [47]. The lack of HCVpp dependence on these $\mathrm{HCV}$-specific host entry factors could be explained by differences in virion composition between HCVpp and HCVcc. Indeed, as discussed above, infectious HCV particles are associated with lipoproteins and contain neutral lipids and apolipoproteins that can potentially play a role during the entry process. Since they are not associated with these host components, HCVpp cannot be used to validate the functions of these host factors in HCV entry. For instance, due to the role of ApoE in virion attachment to heparan sulfate proteoglycans on host cells $[48,49]$, HCVpp cannot be used to study the early steps of virus entry. Similarly, the role of the low density lipoprotein receptor (LDL-R) could not be investigated with the HCVpp model [50]. Investigators need therefore to be aware of this major limitation when studying HCV entry.

\subsection{Characterization of HCV E1E2 envelope glycoprotein functions with HCVpp}

\section{and HCVec systems}

In addition to their contribution to the characterization of $\mathrm{HCV}$-specific host entry factors, HCVpp have also often been used to investigate HCV envelope glycoprotein functions. Since these proteins are produced from a plasmid expressing only E1 and E2 envelope glycoproteins, site-directed mutagenesis can be easily performed and a large number of mutants can be simultaneously investigated. HCVpp have indeed been extensively used to characterize functional regions in HCV envelope glycoproteins (reviewed in [51]). Another 
interesting aspect in using $\mathrm{HCVpp}$ for the characterization of $\mathrm{HCV}$ envelope glycoproteins is that mutations introduced by site-directed mutagenesis are stable, whereas in the context of $\mathrm{HCVcc}$ reversion or second-site mutations can potentially appear. It is worth noting that the entry functions of glycoprotein mutants having a defect in virion assembly cannot be investigated in the HCVcc system, however some of them can be investigated with the help of HCVpp [52]. One needs however to be careful in the interpretation of phenotypes observed with HCVpp. For instance, glycosylation mutants that are infectious in the HCVcc system are not necessarily functional in the HCVpp model [53].

One limitation in investigating the functional role of the viral envelope glycoproteins with the HCVpp and HCVcc systems is that not all the envelope proteins from patient isolates are functional in these systems. Furthermore, in a recent study, no correlation in relative specific infectivity of E1E2-matched HCVcc and HCVpp was observed [31]. This might in part be due to different amounts of E2 on HCVcc virions compared to HCVpp, as well as the presence of ApoE on HCVcc and not on HCVpp [31]. It has been suggested that multiple technical factors can influence production of functional HCVpp, including plasmid transfection ratios and use of either MLV or HIV reporter constructs [54].

An interesting approach that is often used to study the function of viral envelope glycoproteins consists in propagating the virus in serial passages in the presence of an entry inhibitor. This method has been successfully used to identify functional regions in HCV envelope glycoproteins [55-57]. However, this type of approach can only be performed with HCVcc. Similarly, HCVcc adapted to alternative receptors can also be selected to identify cross-talks between HCV envelope glycoproteins and receptors [58, 59].

\subsection{Characterization of antibody neutralization with HCVpp and HCVec systems}


The presence of E1 and E2 at the surface of HCVpp is compatible with the characterization of neutralizing antibodies targeting the two glycoproteins $[8,60]$ as well as cross-neutralizing antibodies [6, 38, 61-62]. Recently, large panels of HCVpp have been produced that encompass more of the diversity of circulating HCV variants, which is critical for accurate measurement of antibody neutralizing breadth [54, 63].

When the HCVcc model was developed, one of its major limitations to study antibody neutralization was the lack of HCV sequence diversity available. However, lately, chimeric full-length viruses, which express diverse E1E2 variants in the context of JFH1-based genome background, have been produced [64-66]. Such panels of HCVcc expressing E1E2 from multiple genotypes have been used to measure neutralizing breadth of broadly neutralizing monoclonal antibodies [67, 68]. More recently, full-length infectious clones from other genotypes have also been developed. They include genotype 1a [69-70], genotypes $2 \mathrm{~b}$ [71] and genotype 3a [72]. These viruses could also be used for the characterization of the neutralizing antibody response. More importantly, they will be essential for the analysis of genotype differences in terms of sensitivity to antivirals.

Very recently, Wasilewski and coworkers generated panels of E1E2-matched HCVcc and HCVpp to compare sensitivity to neutralizing antibodies [31]. Interestingly, they observed a very strong positive correlation between relative neutralization resistance of these same E1E2-matched HCVcc and HCVpp variants, indicating that both systems can be used for the characterization of neutralizing antibodies. However, the HCVpp system is more flexible for this type of study. Comparisons between the two models also showed that HCVpp have a tendency to be more sensitive than HCVcc to antibody neutralization $[31,54]$. This quantitative difference in $\mathrm{HCV} p$ and $\mathrm{HCV} c \mathrm{c}$ neutralization may be explained by the observation that ApoE increases HCVcc neutralization resistance [73]. 
When studying antibody neutralization, it is important to assess viral evolution in the presence of specific monoclonal antibodies to determine their potency to prevent the formation of escape variants. However, this can only be performed with the HCVcc system which allows the virus to be serially passaged in the presence of antibodies [74]. In the same line, the HCVcc system can also be used to identify mutations leading to neutralization escape [75]. An additional advantage of the HCVcc system is that the viral particles produced are infectious in uPA-SCID mice transplanted with human hepatocytes, chimpanzees [30] and genetically humanized mice $[76,77]$. This makes them better tools to study antibody neutralization in pre-clinical models $[62,78]$.

\section{Comparison between HCVpp and HCVcc in terms of production and biosafety}

In addition to all the aspects described in the previous paragraphs, these two viral models present some differences concerning their production both in terms of quantity of virion produced and biosafety level for their manipulation.

As previously described, HCVpp are generated by a single co-transfection of three different plasmids. This represents a limitation in the quantity of pseudoparticles that can be produced. In fact, the concomitant presence of the three plasmids in the same cell and their respective expression are necessary for assembly and release of HCVpp. Conversely, HCVcc virions can be produced in stocks with higher titers than HCVpp, since they can be generated by propagating them in serial passages of infected cells rather than by a single transfection step (Figure 1).

On the other hand, even if it can be a limitation in terms of quantity, the lack of generation of a complete viral cycle for HCVpp represents an advantage in terms of biosafety. Specifically, the lack of HCV genome in HCVpp makes the safety level for manipulation less 
strict for HCVpp than HCVcc. As a consequence, the European legislation authorizes to handle HCVpp in a BSL2 facility, whereas experiments with HCVcc need to be performed in a BSL3 laboratory. To circumvent this problem, one can use a system that supports particle production based on trans-packaging of subgenomic viral RNA which produces virus-like particles that are similar to HCVcc virions [79].

In summary, HCVpp can be produced and handled in a BSL2 facility with a limited quantity of particles produced, while HCVcc can be produced and amplified to reach higher titers, but in more stringent biosafety conditions.

\section{Conclusions}

The establishment of HCVpp and HCVcc systems radically changed the study of the HCV life cycle and represented major advances to investigate virus-host interactions at the cellular level. These two models represent complementary techniques (Table 1) for the study of HCV entry and were extensively used during the past decade for the identification of cellular entry receptors, the characterization of E1E2 glycoproteins and the study of neutralising antibodies (Table 1). It is worth noting that besides these investigations, HCVcc have also been extensively used to study HCV genome replication and assembly. When using HCVcc and HCVpp systems, one needs to keep in mind that the virion composition of these two models is different due to the association of HCVec particles with lipoproteins. As a consequence, experiments performed with these two models can sometimes lead to divergent results. However, in the context of antibody-mediated virus neutralization, the two models seem to produce similar results [31].

In summary, albeit HCVcc represents a more complete tool to study the whole HCV life cycle, HCVpp still represent a useful system to investigate the entry steps directly 
depending on E1 and E2 glycoproteins in a simpler and easier way. The complementary use of these two models represents thus a powerful approach for the characterization of the complex HCV entry steps.

\section{Acknowledgments}

The authors were supported by the French National Agency for Research on AIDS and Viral Hepatitis (ANRS) and the ANR through ERA-NET Infect-ERA program (ANR-13IFEC-0002-01). 


\section{References}

1. Choo QL, Kuo G, Weiner AJ, Overby LR, Bradley DW, Houghton M (1989) Isolation of a cDNA clone derived from a blood-borne non-A, non-B viral hepatitis genome. Science 244:359-362

2. Wakita T, Pietschmann T, Kato T, Date T, Miyamoto M, Zhao Z et al (2005) Production of infectious hepatitis $\mathrm{C}$ virus in tissue culture from a cloned viral genome. Nat Med 11:791-796

3. Lindenbach BD, Evans MJ, Syder AJ, Wolk B, Tellinghuisen TL, Liu CC et al (2005) Complete replication of hepatitis $C$ virus in cell culture. Science 309:623-626

4. Zhong J, Gastaminza P, Cheng G, Kapadia S, Kato T, Burton DR et al (2005) Robust hepatitis C virus infection in vitro. Proc Natl Acad Sci U S A 102:9294-9299

5. Lohmann V, Korner F, Koch J, Herian U, Theilmann L, Bartenschlager R (1999) Replication of subgenomic hepatitis $\mathrm{C}$ virus RNAs in a hepatoma cell line. Science 285:110-113

6. Bartosch B, Dubuisson J, Cosset F-L (2003) Infectious hepatitis C virus pseudo-particles containing functional E1-E2 envelope protein complexes. J Exp Med 197:633-642

7. Drummer HE, Maerz A, Poumbourios P (2003) Cell surface expression of functional hepatitis C virus E1 and E2 glycoproteins. FEBS Lett 546:385-390

8. Hsu M, Zhang J, Flint M, Logvinoff C, Cheng-Mayer C, Rice CM et al (2003) Hepatitis $\mathrm{C}$ virus glycoproteins mediate $\mathrm{pH}$-dependent cell entry of pseudotyped retroviral particles. Proc Natl Acad Sci U S A 100:7271-7276

9. Sherer NM, Lehmann MJ, Jimenez-Soto LF, Ingmundson A, Horner SM, Cicchetti G et al (2003) Visualization of retroviral replication in living cells reveals budding into multivesicular bodies. Traffic 4:785-801

10. Choo QL, Richman KH, Han JH, Berger K, Lee C, Dong C et al (1991) Genetic organization and diversity of the hepatitis C virus. Proc Natl Acad Sci U S A 88:24512455

11. Kolykhalov AA, Feinstone SM, Rice CM (1996) Identification of a highly conserved sequence element at the 3' terminus of hepatitis C virus genome RNA. J Virol 70:33633371

12. Kolykhalov AA, Agapov EV, Blight KJ, Mihalik K, Feinstone SM, Rice CM (1997) Transmission of hepatitis $\mathrm{C}$ by intrahepatic inoculation with transcribed RNA. Science 277:570-574

13. Yanagi M, Purcell RH, Emerson SU, Bukh J (1997) Transcripts from a single full-length cDNA clone of hepatitis $\mathrm{C}$ virus are infectious when directly transfected into the liver of a chimpanzee. Proc Natl Acad Sci U S A 94:8738-8743 
14. Schinazi R, Halfon P, Marcellin P, Asselah T (2014) HCV direct-acting antiviral agents: the best interferon-free combinations. Liver Int 34 Suppl 1:69-78

15. Blight KJ, McKeating JA, Rice CM (2002) Highly permissive cell lines for subgenomic and genomic hepatitis C virus RNA replication. J Virol 76:13001-13014

16. Blight KJ, McKeating JA, Marcotrigiano J, Rice CM (2003) Efficient replication of hepatitis C virus genotype 1a RNAs in cell culture. J Virol 77:3181-3190

17. Ikeda M, Yi M, Li K, Lemon SM (2002) Selectable subgenomic and genome-length dicistronic RNAs derived from an infectious molecular clone of the HCV-N strain of hepatitis C virus replicate efficiently in cultured Huh7 cells. J Virol 76:2997-3006

18. Pietschmann T, Lohmann V, Kaul A, Krieger N, Rinck G, Rutter G et al (2002) Persistent and transient replication of full-length hepatitis $\mathrm{C}$ virus genomes in cell culture. J Virol 76:4008-4021

19. Pietschmann T, Zayas M, Meuleman P, Long G, Appel N, Koutsoudakis G et al (2009) Production of infectious genotype $1 \mathrm{~b}$ virus particles in cell culture and impairment by replication enhancing mutations. PLoS Pathog 5:e1000475

20. Murray CL, Jones CT, Rice CM (2008) Architects of assembly: roles of Flaviviridae non-structural proteins in virion morphogenesis. Nat Rev Microbiol 6:699-708

21. Kato T, Date T, Miyamoto M, Furusaka A, Tokushige K, Mizokami M et al(2003) Efficient replication of the genotype 2a hepatitis $\mathrm{C}$ virus subgenomic replicon. Gastroenterol 125:1808-1817

22. Kato T, Furusaka A, Miyamoto M, Date T, Yasui K, Hiramoto J et al (2001) Sequence analysis of hepatitis $\mathrm{C}$ virus isolated from a fulminant hepatitis patient. J Med Virol 64:334-339.

23. Zhong J, Gastaminza P, Chung J, Stamataki Z, Isogawa M, Cheng G et al (2006) Persistent hepatitis $\mathrm{C}$ virus infection in vitro: coevolution of virus and host. J Virol 80:11082-11093

24. Kaul A, Woerz I, Meuleman P, Leroux-Roels G, Bartenschlager R (2007) Cell culture adaptation of hepatitis $\mathrm{C}$ virus and in vivo viability of an adapted variant. J Virol 81:13168-13179

25. Russell RS, Meunier J-C, Takikawa S, Faulk K, Engle RE, Bukh J et al (2008) Advantages of a single-cycle production assay to study cell culture-adaptive mutations of hepatitis C virus. Proc Natl Acad Sci U S A 105:4370-4375

26. Andre P, Komurian-Pradel F, Deforges S, Perret M, Berland JL, Sodoyer M et al (2002) Characterization of low- and very-low-density hepatitis C virus RNA-containing particles. J Virol 76:6919-6928

27. Meunier J-C, Russell RS, Engle RE, Faulk KN, Purcell RH, Emerson SU (2008) Apolipoprotein c1 association with hepatitis C virus. J Virol 82:9647-9656 
28. Merz A, Long G, Hiet M-S, Brugger B, Chlanda P, Andre P et al (2011) Biochemical and morphological properties of hepatitis $\mathrm{C}$ virus particles and determination of their lipidome. J Biol Chem 286:3018-3032

29. Catanese MT, Uryu K, Kopp M, Edwards TJ, Andrus L, Rice WJ et al (2013) Ultrastructural analysis of hepatitis C virus particles. Proc Natl Acad Sci U S A 110:9505-9510

30. Lindenbach BD, Meuleman P, Ploss A, Vanwolleghem T, Syder AJ, McKeating JA et al (2006) Cell culture-grown hepatitis $C$ virus is infectious in vivo and can be recultured in vitro. Proc Natl Acad Sci U S A 103:3805-3809

31. Wasilewski L, Ray S, Bailey JR (2016) Hepatitis C virus resistance to broadly neutralizing antibodies measured using replication competent virus and pseudoparticles. J Gen Virol 97:2883-2893

32. Vieyres G, Thomas X, Descamps V, Duverlie G, Patel AH, Dubuisson J (2010) Characterization of the envelope glycoproteins associated with infectious hepatitis $\mathrm{C}$ virus. J Virol 84:10159-10168

33. Op De Beeck A, Voisset C, Bartosch B, Ciczora Y, Cocquerel L, Keck Z et al (2004) Characterization of functional hepatitis $C$ virus envelope glycoproteins. J Virol 78:29943002

34. Flint M, Logvinoff C, Rice CM, McKeating JA (2004) Characterization of infectious retroviral pseudotype particles bearing hepatitis $\mathrm{C}$ virus glycoproteins. J Virol 78:68756882

35. Pileri P, Uematsu Y, Campagnoli S, Galli G, Falugi F, Petracca R et al (1998) Binding of hepatitis C virus to CD81. Science 282:938-941

36. Scarselli E, Ansuini H, Cerino R, Roccasecca RM, Acali S, Filocamo G et al (2002) The human scavenger receptor class B type $\mathrm{I}$ is a novel candidate receptor for the hepatitis $\mathrm{C}$ virus. EMBO J 21:5017-5025

37. Zhang J, Randall G, Higginbottom A, Monk P, Rice CM, McKeating JA (2004) CD81 is required for hepatitis $C$ virus glycoprotein-mediated viral infection. J Virol 78:14481455

38. Bartosch B, Vitelli A, Granier C, Goujon C, Dubuisson J, Pascale S et al (2003) Cell entry of hepatitis $\mathrm{C}$ virus requires a set of co-receptors that include the CD81 tetraspanin and the SR-B1 scavenger receptor. J Biol Chem 278:41624-41630

39. Zeisel MB, Koutsoudakis G, Schnober EK, Haberstroh A, Blum HE, Cosset F-L et al (2007) Scavenger receptor class B type I is a key host factor for hepatitis C virus infection required for an entry step closely linked to CD81. Hepatol 46:1722-1731

40. Evans MJ, von Hahn T, Tscherne DM, Syder AJ, Panis M, Wolk B et al (2007) Claudin1 is a hepatitis $C$ virus co-receptor required for a late step in entry. Nature 446:801-805 
41. Ploss A, Evans MJ, Gaysinskaya VA, Panis M, You H, de Jong YP et al (2009) Human occludin is a hepatitis $\mathrm{C}$ virus entry factor required for infection of mouse cells. Nature 457:882-886

42. Li Q, Sodroski C, Lowey B, Schweitzer CJ, Cha H, Zhang F et al (2016) Hepatitis C virus depends on E-cadherin as an entry factor and regulates its expression in epithelialto-mesenchymal transition. Proc Natl Acad Sci U S A 113:7620-7625

43. Martin DN, Uprichard SL (2013) Identification of transferrin receptor 1 as a hepatitis C virus entry factor. Proc Natl Acad Sci U S A 110:10777-10782

44. Ujino S, Nishitsuji H, Hishiki T, Sugiyama K, Takaku H, Shimotohno K (2016) Hepatitis C virus utilizes VLDLR as a novel entry pathway. Proc Natl Acad Sci U S A 113:188-193

45. Lupberger J, Zeisel MB, Xiao F, Thumann C, Fofana I, Zona L et al (2011) EGFR and EphA2 are host factors for hepatitis $\mathrm{C}$ virus entry and possible targets for antiviral therapy. Nat Med 17:589-595

46. Sainz BJ, Barretto N, Martin DN, Hiraga N, Imamura M, Hussain S et al (2012) Identification of the Niemann-Pick C1-like 1 cholesterol absorption receptor as a new hepatitis C virus entry factor. Nat Med 18:281-285

47. Gerold G, Meissner F, Bruening J, Welsch K, Perin PM, Baumert TF et al (2015) Quantitative proteomics identifies serum response factor binding protein 1 as a host factor for hepatitis C virus entry. Cell Rep 12:864-878

48. Jiang J, Cun W, Wu X, Shi Q, Tang H, Luo G (2012) Hepatitis C virus attachment mediated by apolipoprotein E binding to cell surface heparan sulfate. J Virol 86:72567267

49. Xu Y, Martinez P, Seron K, Luo G, Allain F, Dubuisson J et al (2015) Characterization of hepatitis $\mathrm{C}$ virus interaction with heparan sulfate proteoglycans. J Virol 89:3846-3858

50. Albecka A, Belouzard S, Op de Beeck A, Descamps V, Goueslain L, Bertrand-Michel J et al (2012) Role of low-density lipoprotein receptor in the hepatitis $\mathrm{C}$ virus life cycle. Hepatol 55:998-1007

51. Vieyres G, Dubuisson J, Pietschmann T (2014) Incorporation of hepatitis C virus E1 and E2 glycoproteins: the keystones on a peculiar virion. Viruses 6:1149-1187

52. Falson P, Bartosch B, Alsaleh K, Tews BA, Loquet A, Ciczora Y et al (2015) Hepatitis $\mathrm{C}$ virus envelope glycoprotein $\mathrm{E} 1$ forms trimers at the surface of the virion. J Virol 89:10333-10346

53. Helle F, Vieyres G, Elkrief L, Popescu C-I, Wychowski C, Descamps V et al (2010) Role of $\mathrm{N}$-linked glycans in the functions of hepatitis $\mathrm{C}$ virus envelope proteins incorporated into infectious virions. J Virol 84:11905-11915

54. Urbanowicz RA, McClure CP, King B, Mason CP, Ball JK, Tarr AW (2016) Novel functional hepatitis $\mathrm{C}$ virus glycoprotein isolates identified using an optimized viral pseudotype entry assay. J Gen Virol 97:2265-2279 
55. Fénéant L, Potel J, François C, Sané F, Douam F, Belouzard S et al (2015) New insights into the understanding of hepatitis $\mathrm{C}$ virus entry and cell-to-cell transmission by using the ionophore monensin A. J Virol 89:8346-8364

56. Vausselin T, Seron K, Lavie M, Mesalam AA, Lemasson M, Belouzard S et al (2016) Identification of a new benzimidazole derivative as an antiviral against hepatitis $\mathrm{C}$ virus. J Virol 90:8422-8434

57. Perin PM, Haid S, Brown RJP, Doerrbecker J, Schulze K, Zeilinger C et al (2016) Flunarizine prevents hepatitis $\mathrm{C}$ virus membrane fusion in a genotype-dependent manner by targeting the potential fusion peptide within E1. Hepatol 63:49-62

58. Bitzegeio J, Bankwitz D, Hueging K, Haid S, Brohm C, Zeisel MB et al (2010) Adaptation of hepatitis C virus to mouse CD81 permits infection of mouse cells in the absence of human entry factors. PLoS Pathog 6:e1000978

59. Hopcraft SE, Evans MJ (2015) Selection of a hepatitis C virus with altered entry factor requirements reveals a genetic interaction between the $\mathrm{E} 1$ glycoprotein and claudins. Hepatol 62:1059-1069

60. Cai Z, Zhang C, Chang K-S, Jiang J, Ahn B-C, Wakita T et al (2005) Robust production of infectious hepatitis $\mathrm{C}$ virus (HCV) from stably HCV cDNA-transfected human hepatoma cells. J Virol 79:13963-13973

61. Owsianka A, Tarr AW, Juttla VS, Lavillette D, Bartosch B, Cosset F-L et al (2005) Monoclonal antibody AP33 defines a broadly neutralizing epitope on the hepatitis C virus E2 envelope glycoprotein. J Virol 79:11095-11104

62. Law M, Maruyama T, Lewis J, Giang E, Tarr AW, Stamataki Z et al (2008) Broadly neutralizing antibodies protect against hepatitis $\mathrm{C}$ virus quasispecies challenge. Nat Med $14: 25-27$

63. Osburn WO, Snider AE, Wells BL, Latanich R, Bailey JR, Thomas DL et al (2014) Clearance of hepatitis $\mathrm{C}$ infection is associated with the early appearance of broad neutralizing antibody responses. Hepatol 59:2140-2151

64. Gottwein JM, Scheel TKH, Hoegh AM, Lademann JB, Eugen-Olsen J, Lisby G et al (2007) Robust hepatitis $C$ genotype 3 a cell culture releasing adapted intergenotypic 3a/2a (S52/JFH1) viruses. Gastroenterol 133:1614-1626

65. Gottwein JM, Scheel TKH, Jensen TB, Lademann JB, Prentoe JC, Knudsen ML et al (2009) Development and characterization of hepatitis C virus genotype 1-7 cell culture systems: role of CD81 and scavenger receptor class B type I and effect of antiviral drugs. Hepatol 49:364-377

66. Scheel TKH, Gottwein JM, Carlsen THR, Li Y-P, Jensen TB, Spengler U et al (2011) Efficient culture adaptation of hepatitis $C$ virus recombinants with genotype-specific core-NS 2 by using previously identified mutations. J Virol 85:2891-2906

67. Keck Z, Xia J, Wang Y, Wang W, Krey T, Prentoe J et al (2012) Human monoclonal antibodies to a novel cluster of conformational epitopes on HCV E2 with resistance to neutralization escape in a genotype 2a isolate. PLoS Pathog 8:e1002653 
68. Carlsen THR, Pedersen J, Prentoe JC, Giang E, Keck Z-Y, Mikkelsen LS et al (2014) Breadth of neutralization and synergy of clinically relevant human monoclonal antibodies against HCV genotypes 1a, 1b, 2a, 2b, 2c, and 3a. Hepatol 60:1551-1562

69. Li Y-P, Ramirez S, Jensen SB, Purcell RH, Gottwein JM, Bukh J (2012) Highly efficient full-length hepatitis $\mathrm{C}$ virus genotype 1 (strain TN) infectious culture system. Proc Natl Acad Sci U S A 109:19757-19762

70. Li Y-P, Ramirez S, Mikkelsen L, Bukh J (2015) Efficient infectious cell culture systems of the hepatitis C virus (HCV) prototype strains HCV-1 and H77. J Virol 89:811-823

71. Ramirez S, Li Y-P, Jensen SB, Pedersen J, Gottwein JM, Bukh J (2014) Highly efficient infectious cell culture of three hepatitis $C$ virus genotype $2 b$ strains and sensitivity to lead protease, nonstructural protein 5A, and polymerase inhibitors. Hepatol 59:395-407

72. Ramirez S, Mikkelsen LS, Gottwein JM, Bukh J (2016) Robust HCV Genotype 3a Infectious Cell Culture System Permits Identification of Escape Variants With Resistance to Sofosbuvir. Gastroenterol 151:973-985

73. Fauvelle C, Felmlee DJ, Crouchet E, Lee J, Heydmann L, Lefevre M et al (2016) Apolipoprotein $\mathrm{E}$ mediates evasion from hepatitis $\mathrm{C}$ virus neutralizing antibodies. Gastroenterol 150:206-217

74. Keck Z, Angus AGN, Wang W, Lau P, Wang Y, Gatherer D et al (2014) Non-random escape pathways from a broadly neutralizing human monoclonal antibody map to a highly conserved region on the hepatitis $\mathrm{C}$ virus E2 glycoprotein encompassing amino acids 412-423. PLoS Pathog 10:e1004297

75. Gal-Tanamy M, Keck Z-Y, Yi M, McKeating JA, Patel AH, Foung SKH et al (2008) In vitro selection of a neutralization-resistant hepatitis $\mathrm{C}$ virus escape mutant. Proc Natl Acad Sci U S A 105:19450-19455

76. Dorner M, Horwitz JA, Robbins JB, Barry WT, Feng Q, Mu K et al (2011) A genetically humanized mouse model for hepatitis C virus infection. Nature 474:208-211

77. Dorner M, Horwitz JA, Donovan BM, Labitt RN, Budell WC, Friling T et al (2013) Completion of the entire hepatitis $\mathrm{C}$ virus life cycle in genetically humanized mice. Nature 501:237-241

78. de Jong YP, Dorner M, Mommersteeg MC, Xiao JW, Balazs AB, Robbins JB et al (2014) Broadly neutralizing antibodies abrogate established hepatitis $C$ virus infection. Sci Transl Med 6:254ra129

79. Steinmann E, Brohm C, Kallis S, Bartenschlager R, Pietschmann T (2008) Efficient trans-encapsidation of hepatitis $\mathrm{C}$ virus RNAs into infectious virus-like particles. J Virol 82:7034-7046

FIGURE 1. HCVpp. HCVpp are produced through the co-transfection of 293 T cells with 
three plasmids respectively coding for the HIV or MLV gag-pol, the reporter gene Firefly Luciferase and HCV glycoproteins E1 and E2 from a specific genotype. The co-transfection drives the assembly of pseudoparticles constituted by a viral capsid containing the minigenome coding for the reporter gene and an envelope in which are inserted the HCV glycoproteins. These pseudoparticles are released by the cells and can be collected and used to infect permissive cell lines, allowing the quantification of the entry process through measurement of the reporter gene activity. HCVcc. A plasmid coding for the HCV cDNA is transcribed in vitro thanks to the presence of a T7 RNA polymerase promoter. The synthesized HCV RNA is then electroporated in hepatoma cells (Huh-7 or Huh-7.5 cells), giving rise to the translation of all the viral proteins and to the generation of a complete infection cycle. The virions secreted can be collected and used to infect new hepatoma cells. Sequential passages of the supernatant on new permissive cells enable the amplification of the virus and the increase of the viral titre. 
TABLE 1. HCVpp and HCVec properties

\begin{tabular}{|c|c|c|}
\hline & HCVpp & HCVec \\
\hline VLDL/LDL association & No & Yes \\
\hline Apolipoprotein association & No & Yes \\
\hline $\begin{array}{l}\text { E1 and E2 envelope } \\
\text { glycoproteins }\end{array}$ & Non-covalent E1E2 heterodimers & $\begin{array}{l}\text { Large covalent complexes stabilized } \\
\text { by disulfide bridges }\end{array}$ \\
\hline $\begin{array}{l}\text { Degree of heterogeneity in } \\
\text { E1E2 }\end{array}$ & High & Low \\
\hline Study of E1E2 glycoproteins & Entry & Entry, assembly and secretion \\
\hline Stability of mutations & Stable & $\begin{array}{c}\text { Possibility of reversion or second-site } \\
\text { mutation }\end{array}$ \\
\hline $\begin{array}{l}\text { Characterization of entry } \\
\text { factors }\end{array}$ & E1E2-dependent interactions & $\begin{array}{l}\text { E1E2-dependent interactions } \\
\text { Lipid receptors and apolipoprotein- } \\
\text { dependent interactions }\end{array}$ \\
\hline $\begin{array}{l}\text { Selection of E1E2 adaptation } \\
\text { to alternative receptors }\end{array}$ & No & Yes \\
\hline $\begin{array}{l}\text { Selection of drug-resistant } \\
\text { variants }\end{array}$ & No & Yes \\
\hline $\begin{array}{l}\text { Selection of neutralization } \\
\text { escape mutants }\end{array}$ & No & Yes \\
\hline $\begin{array}{l}\text { Sensitivity to antibody } \\
\text { neutralization }\end{array}$ & Highly sensitive & Sensitive \\
\hline $\begin{array}{l}\text { Study of antibody } \\
\text { neutralization in animal } \\
\text { models }\end{array}$ & No & Yes \\
\hline Viral production & Limited to one co-transfection & $\begin{array}{c}\text { Can be amplified by sequential } \\
\text { passages in cell culture }\end{array}$ \\
\hline Biosafety level* & BSL2 & BSL3 \\
\hline
\end{tabular}

* According to the European Union legislation 


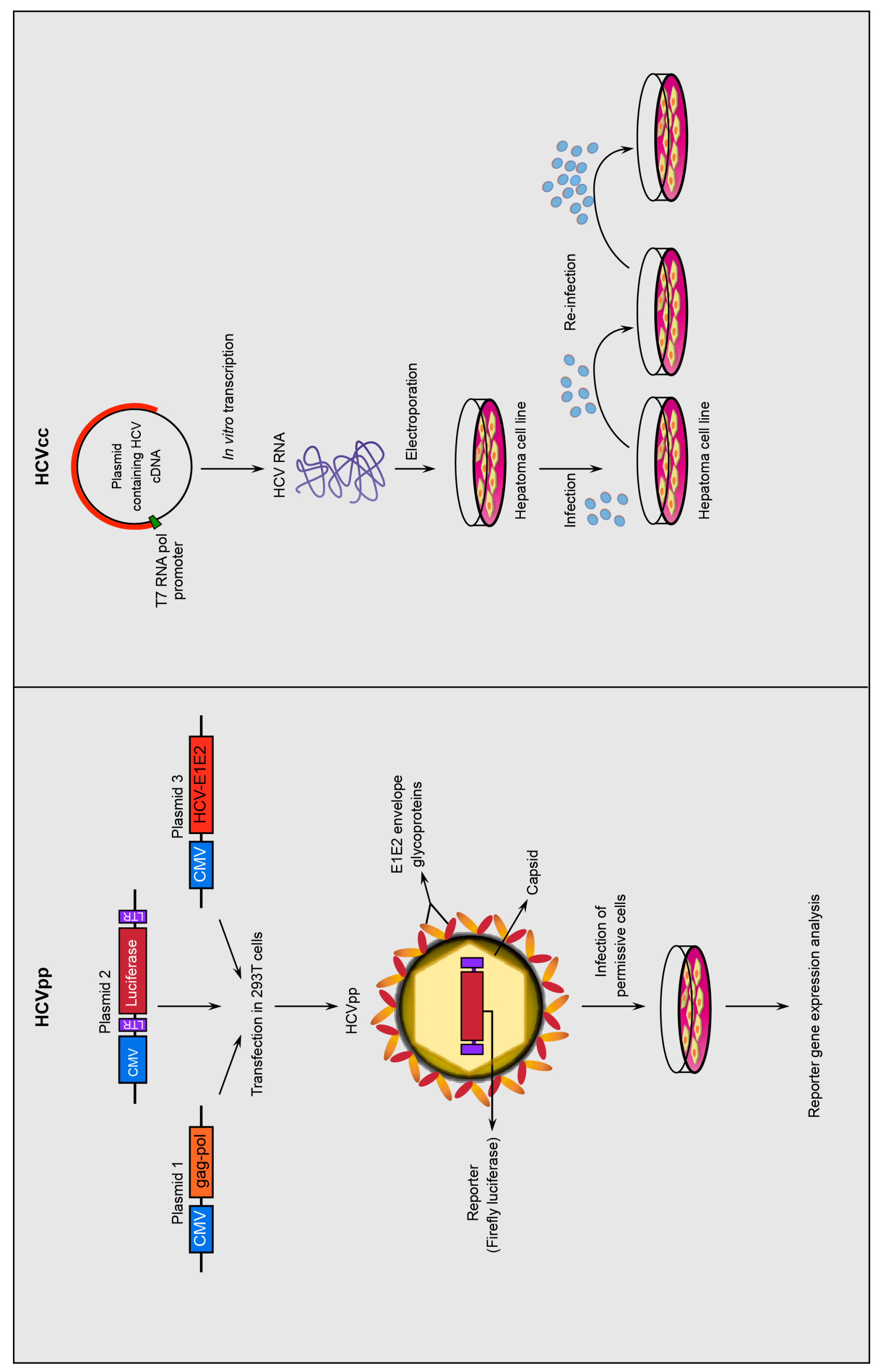

